\title{
PEMILIHAN KRITERIA DALAM PEMBUATAN KARTU KREDIT DENGAN MENGGUNAKAN METODE FUZZY AHP
}

\author{
Joko Hadi Aprianto ${ }^{1}$, G. K. Gandhiadi ${ }^{2}$, Desak PUtu Eka Nilakusmawati ${ }^{3}$ \\ 1,2,3 Jurusan Matematika FMIPA Universitas Udayana, Bukit Jimbaran-Bali \\ e-mail: 1joko.hadi09@yahoo.com, ${ }^{2}$ gandhiadigk@yahoo.com, \\ ${ }^{3}$ nilakusmawati_desak@yahoo.com
}

\begin{abstract}
The rise of credit card users, make banks compete to provide a wide range of offers to attract customers. This study aims to determine the priority criteria selected customers for establishment credit cards by using a fuzzy AHP method. Method fuzzy AHP is a combination of the AHP method and fuzzy method. Fuzzy AHP approach particularly triangular fuzzy number approach to the AHP scale should be able to minimize uncertainty for the results obtained are more accurate. The criteria used for this study is the interest rate, the promo/discount, limit, and annual dues. Based on the steps of calculation of data obtained fuzzy AHP respondents have value CR $=0.049$, which means consistent because it meets the standards set $\mathrm{CR}<0.10$ and that became the order of priority are limit, promo/discount, interest rate, and continued with weights of priorities are $0408,0.28,0.16$, and 0.152 .
\end{abstract}

Keywords: AHP, Fuzzy Analytic Hierarchy Process (FAHP), Criteria of Credit Card, Consistensy Ratio, Weight Priority

\section{Pendahuluan}

Mengikuti perkembangan zaman saat ini, aspek finansial yang berkembang pesat dalam satu sisi kehidupan masyarakat adalah maraknya penggunaan kartu kredit. Kartu kredit merupakan alat pembayaran pengganti uang tunai dan dapat digunakan di tempattempat yang bersedia menerima pembayaran menggunakan kartu kredit yang dimiliki oleh orang tersebut (Suyatno, T., dkk. 1997).

Pada penelitian ini akan dipelajari prioritas kriteria nasabah dalam pembuatan kartu kredit di suatu bank. Metode yang digunakan untuk menentukan prioritas tersebut adalah Fuzzy Analytic Hierarchy Process (FAHP). Fuzzy Analytic Hierarchy Process (FAHP) merupakan salah satu metode yang dipakai untuk mendukung keputusan. Metode ini merupakan gabungan dari metode Analytic Hierarchy Process (AHP) dan pendekatan fuzzy khususnya pendekatan triangular fuzzy number.

Logika fuzzy merupakan sebuah logika yang memiliki nilai kekaburan atau kesamaran (Fuzzyness) antara dua nilai. Pendekatan fuzzy khususnya pendekatan triangular fuzzy number terhadap skala AHP diharapkan mampu untuk meminimalisasi ketidakpastian sehingga diharapkan hasil yang diperoleh lebih akurat (Kusumadewi dan Purnomo, 2010).

Berdasarkan latar belakang masalah, maka yang menjadi rumusan permasalahan dalam penelitian ini adalah bagaimana membangun sistem pengambilan keputusan pemilihan kriteria dalam pembuatan kartu kredit dengan menggunakan metode Fuzzy Analitical Hierarchy Process (FAHP) sebagai alat bantu dalam mengambil keputusan untuk menentukan prioritas kriteria yang akan dipilih.

\footnotetext{
${ }^{1}$ Mahasiswa Jurusan Matematika FMIPA Universitas Udayana

${ }^{2}$ Staf Pengajar Jurusan Matematika FMIPA Universitas Udayana
} 
Tujuan dari penelitian ini adalah untuk membangun sistem pengambilan keputusan sebagai alat bantu dalam mengambil keputusan untuk menentukan urutan prioritas kriteria yang akan dipilih nasabah dalam pembuatan kartu kredit dan menerapakan metode FAHP dalam sistem pengambilan keputusan studi kasus pemilihan kriteria dalam pembuatan kartu kredit.

Dalam penelitian ini, untuk menghindari terlalu luasnya masalah, maka batasan kriteriakriteria yang dipakai dalam pembuatan kartu kredit adalah suku bunga, promo/diskon, limit, dan iuran tahunan. Sistem pendukung keputusan yang dirancang yaitu menggunakan metode fuzzy AHP.

Penelitian ini diharapkan dapat memberikan manfaat sebagai bahan masukan atau informasi bagi bank penerbit kartu kredit tentang kriteria prioritas nasabah dalam pembuatan kartu kredit. Hasil penelitian ini juga bermanfaat sebagai acuan pengambilan keputusan dalam meningkatkan kuantitas nasabah pengguna kartu kredit.

\section{Ulasan Pustaka}

\subsection{Analytical Hierarchy Process (AHP)}

AHP merupakan suatu metode pengambilan keputusan dan suatu teori pengukuran yang digunakan untuk mengukur skala rasio, baik dari perbandingan-perbandingan berpasangan diskrit maupun kontinu (Saaty, 1987).

Tahapan-tahapan proses dalam metode AHP (Apriyanto, 2008) adalah:

a) Mendefinisikan masalah dan tujuan yang diinginkan.

b) Membuat struktur hirarki yang diawali dengan tujuan, kriteria-kriteria dan alternatif-alternatif pilihan.

c) Membentuk matriks perbandingan berpasangan terhadap masing-masing kriteria untuk analisis numerik.Nilai numerik yang diberikan untuk seluruh perbandingan diperoleh dari skala 1 sampai 9 yang telah ditetapkan, seperti tampak pada Tabel 1.

Tabel 1. Skala Penilaian Perbandingan Berpasangan

\begin{tabular}{|c|l|}
\hline $\begin{array}{c}\text { Tingkat } \\
\text { Kepentingan }\end{array}$ & \multicolumn{1}{c|}{ Definisi } \\
\hline 1 & Sama penting \\
\hline 3 & Sedikit lebih penting \\
\hline 5 & Lebih penting \\
\hline 7 & Sangat penting \\
\hline 9 & Mutlak lebih penting \\
\hline $2,4,6,8$ & $\begin{array}{l}\text { Nilai diantara dua pilihan yang } \\
\text { berdekatan }\end{array}$ \\
\hline Resiprokal & Kebalikan \\
\hline
\end{tabular}

Sumber: Saaty, T. L. and L. G. Vargas (2012)

d) Menguji konsistensi hirarki. Jika nilai konsistensi rasio yang dihasilkan tidak memenuhi standar yang ditetapkan yaitu Consistency Ratio (CR) $<0,1$ maka penilaian harus diulang kembali.

\subsection{Eigen value dan Eigen vector}

Jika matriks $A$ berukuran $n x n$, dapat didiagonalkan dan $\lambda_{1}, \lambda_{2}, \ldots, \lambda_{n}$ merupakan nilai eigen dari $A$ yang memenuhi hubungan

$$
\left|\lambda_{1}\right|>\left|\lambda_{2}\right| \geq \cdots\left|\lambda_{n}\right|>0
$$

Karena matriks $A$ dapat didiagonalkan, vektor eigen $\bar{v}_{1}, \ldots, \bar{v}_{n} \quad$ masing-masing berkaitan dengan eigen $\lambda_{1}, \lambda_{2}, \ldots, \lambda_{n}$ dan membentuk basis di $R^{n}$. sehingga sebarang vektor $\bar{x}_{0}$ di $R^{n}$ dapat dituliskan sebagai (Budhi, 1995):

$\bar{x}_{0}=s_{1} \bar{v}_{1}+s_{2} \bar{v}_{2}+\ldots+s_{n} \bar{v}_{n}(1)$

Jika persamaan (1) dikalikan denganA, diperoleh

$$
\begin{array}{rl}
A \bar{x}_{0}=A\left(s_{1} \bar{v}_{1}+s_{2} \bar{v}_{2}\right. & \left.+\ldots+s_{n} \bar{v}_{n}\right) \\
=s_{1} A \bar{v}_{1}+s_{2} & A \bar{v}_{2}+\ldots+s_{n} A \bar{v}_{n} \\
& =s_{1} \lambda_{1} \bar{v}_{1} \\
& +s_{2} \lambda_{2} \bar{v}_{2}+\ldots \\
& +s_{n} \lambda_{n} \bar{v}_{n}
\end{array}
$$

Dari hasil $A \bar{x}_{0}$ untuk memperoleh $A^{k} \bar{x}_{0}$ maka dilakukan perkalian dari hasil terakhir 
dengan A, hal ini dilakukan berulang-ulang sampai dengan $k$ kali.

$$
\begin{aligned}
& A^{k} \bar{x}_{0}=s_{1} \lambda_{1}^{k} \bar{v}_{1}+s_{2} \lambda_{2}^{k} \bar{v}_{2}+\ldots+s_{n} \lambda_{n}^{k} \bar{v}_{n} \\
= & \lambda_{1}^{k}\left(s_{1} \bar{v}_{1}+s_{2}\left(\frac{\lambda_{2}}{\lambda_{1}}\right)^{k} \bar{v}_{2}+\ldots+s_{n}\left(\frac{\lambda_{n}}{\lambda_{1}}\right)^{k} \bar{v}_{n}\right)
\end{aligned}
$$

Jika $k$ makin besar, nilai $\left(\frac{\lambda_{i}}{\lambda_{1}}\right)^{k}$ akan makin kecil untuk $i=2, \ldots, n$, karena $\left|\frac{\lambda_{i}}{\lambda_{1}}\right|<1$.

Oleh karena itu, untuk $k$ yang cukup besar pada persamaan (2) kurang lebih akan menjadi

$$
A^{k} \bar{x}_{0} \approx s_{1} \lambda_{1}^{k} \bar{v}_{1}
$$

Persamaan (3) merupakan hampiran dari kelipatan vektor eigen $\bar{v}_{1}$ tersebut, yaitu vektor $A^{k} \bar{x}_{0}$. Vektor $A^{k} \bar{x}_{0}$ merupakan hampiran vektor eigen yang berkaitan dengan nilai eigen terbesar $\bar{v}_{1}$. Makin besar nilai $k$ makin baik pula hampiran $A^{k} \bar{x}_{0}$ terhadap sebuah vektor eigen dari $A$.

Setelah diperoleh vektor eigen $\bar{v}_{1}$ atau kelipatannya, nilai eigen yang berkaitan dapat dihitung sebagai berikut. Karena $A \bar{v}_{1}=\lambda_{1} \bar{v}_{1}$, maka

$$
A \bar{v}_{1} \bar{v}_{1}=\lambda_{1} \bar{v}_{1} \bar{v}_{1}
$$

atau

$$
\lambda_{1}=\frac{A \bar{v}_{1} \bar{v}_{1}}{\bar{v}_{1} \bar{v}_{1}}
$$

Rumus nilai eigen ini disebut rumus pembagian Rayleigh (Budhi, 1995).

\subsection{Uji Konsistensi dan Indeks Rasio dan FAHP}

Dengan metode AHP yang memakai persepsi pembuat keputusan sebagai inputnya maka ketidakkonsistenan mungkin terjadi karena manusia memiliki keterbatasan dalam menyatakan persepsinya. Berdasarkan kondisi ini, untuk menunjukkan matriks berordo $n$ konsisten dapat diperoleh melalui langkahlangkah berikut ini (Saaty, T, L, and L, G. Vargas, 2012):

1. Menentukan nilai vektor eigen dan $\lambda_{\max }$
2. Menentukan nilai Consistency Index yang dapat diperoleh dengan persamaan:

$$
\mathbf{C I}=\frac{\left(\lambda_{\max }-\boldsymbol{n}\right)}{(\boldsymbol{n}-\mathbf{1})}
$$

dengan,

$$
\begin{array}{cc}
\text { CI }=\text { Rasio penyimpangan (deviasi) } & \text { konsistensi (consistency index) } \\
\lambda_{\max }= & \begin{array}{c}
\text { Nilai eigen terbesar dari matriks } \\
\text { berordo } \mathrm{n}
\end{array} \\
\boldsymbol{N} \quad=\text { Ordo matriks }
\end{array}
$$

Apabila CI bernilai nol, maka pair-wise comparison matrix tersebut konsisten. Batas ketidakkonsistenan (inconsistency) yang telah ditetapkan oleh Saaty (1987) ditentukan dengan menggunakan Rasio Konsistensi (CR), yaitu perbandingan indeks konsistensi (CI) dengan nilai random indeks (RI) yang diperlihatkan pada Tabel 2. Nilai ini bergantung pada ordo matriks $n$. Dengan demikian, Rasio Konsistensi dapat dirumuskan sebagai berikut:

$$
\mathrm{CR}=\frac{C I}{R I}
$$

\section{$\mathbf{C R}=$ Consistency Ratio $\mathbf{R I}=$ RandomIndex}

Tabel 2. Nilai Random Indeks (RI)

\begin{tabular}{|l|l|l|l|l|l|l|l|l|l|l|}
\hline $\mathrm{N}$ & 1 & 2 & 3 & 4 & 5 & 6 & 7 & 8 & 9 & 10 \\
\hline $\mathrm{R}$ & 0. & 0. & 0. & 0. & 1. & 1. & 1. & 1. & 1. & 1. \\
$\mathrm{I}$ & 00 & 00 & 52 & 89 & 11 & 25 & 35 & 40 & 45 & 49 \\
\hline
\end{tabular}

Sumber: Saaty, T. L. and L. G. Vargas (2012)

Bila matriks pair-wise comparison mempunyai nilai $\mathrm{CR} \quad<0,100$ maka ketidakkonsistenan pendapat dari pengambil keputusan masih dapat diterima dan apabila tidak demikian maka penilaian harus diulang.

Jika hasil memenuhi $\mathrm{CR}<0,100$ maka dilakukan pengubahan bobot penilaian perbandingan berpasangan pada skala AHP ke dalam bilangan triangular fuzzy (Chang, D.Y., 1992). 
Tabel 3. Fungsi Keanggotaan Bilangan Fuzzy

\begin{tabular}{|l|l|l|}
\hline \multicolumn{1}{|c|}{ Skala Fuzzy } & $\begin{array}{c}\text { Invers Skala } \\
\text { Fuzzy }\end{array}$ & \multicolumn{1}{|c|}{ Definisi } \\
\hline $\begin{array}{l}1 \text { dengan nilai } \\
\text { TF }(1,1,1)\end{array}$ & $(1,1,1)$ & Sama penting \\
\hline $\begin{array}{l}2 \text { dengan nilai } \\
\text { TF }(1 / 2,1,3 / 2)\end{array}$ & $(2 / 3,1,2)$ & Pertengahan \\
\hline $\begin{array}{l}3 \text { dengan nilai } \\
\text { TF }(1,3 / 2,2)\end{array}$ & $(1 / 2,2 / 3,1)$ & $\begin{array}{l}\text { Sedikit lebih } \\
\text { penting }\end{array}$ \\
\hline $\begin{array}{l}4 \text { dengan nilai } \\
\text { TF }(3 / 2,2,5 / 2)\end{array}$ & $(2 / 5,1 / 2,2 / 3)$ & Pertengahan \\
\hline $\begin{array}{l}5 \text { dengan nilai } \\
\text { TF }(2,5 / 2,3)\end{array}$ & $(1 / 3,2 / 5,1 / 2)$ & Lebih penting \\
\hline $\begin{array}{l}6 \text { dengan nilai } \\
\text { TF }(5 / 2,3,7 / 2)\end{array}$ & $(2 / 7,1 / 3,2 / 5)$ & Pertengahan \\
\hline $\begin{array}{l}7 \text { dengan nilai } \\
\text { TF }(3,7 / 2,4)\end{array}$ & $(1 / 4,2 / 7,1 / 3)$ & Sangat penting \\
\hline $\begin{array}{l}8 \text { dengan nilai } \\
\text { TF }(7 / 2,4,9 / 2)\end{array}$ & $(2 / 9,1 / 4,2 / 7)$ & Pertengahan \\
\hline $\begin{array}{l}9 \text { dengan nilai } \\
\text { TF }(4,9 / 2,9 / 2)\end{array}$ & $(2 / 92 / 9,1 / 4)$ & $\begin{array}{l}\text { Mutlak lebih } \\
\text { penting }\end{array}$ \\
\hline
\end{tabular}

Sumber: Chang, D.Y. (1992)

Selanjutnya diberikan aturan-aturan operasi aritmatika triangular fuzzy number yang umum digunakan. Misalkan terdapat 2 TFN yaitu: $M_{1}=\left(l_{1}, m_{1}, u_{1}\right) \operatorname{dan} M_{2}=$ $\left(l_{2}, m_{2}, u_{2}\right)$, berlaku

$$
\begin{aligned}
& M_{1} \oplus M_{2}=\left(l_{1}+l_{2}, m_{1}+m_{2}, u_{1}+u_{2}\right) \\
& M_{1} \ominus M_{2}=\left(l_{1}-l_{2}, m_{1}-m_{2}, u_{1}-u_{2}\right) \\
& M_{1} \otimes M_{2}=\left(l_{1} \cdot l_{2}, m_{1} \cdot m_{2}, u_{1} \cdot u_{2}\right) \\
& \lambda \otimes M_{2}=\left(\lambda . l_{2}, \lambda . m_{2}, \lambda . u_{2}\right) \\
& M_{1}^{-1} \quad=\left(1 / u_{1}, 1 / m_{1}, 1 / l_{1}\right)
\end{aligned}
$$

Dari matriks triangular fuzzy ditentukan nilai fuzzy synthetic extent untuk setiap kriteria (Chang, D. Y. 1996).

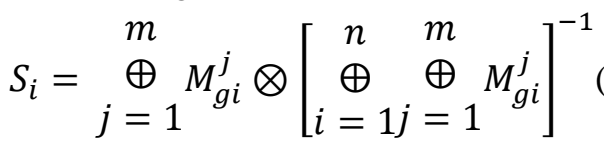

Setelah itu membandingkan nilai fuzzy synthetic extent $\left(S_{i} \geq S_{k}\right)$. Dari hasil perbandingan nilai fuzzy synthetic extent $\left(S_{i} \geq S_{k}\right)$ maka diambil nilai minimumnya, yaitu: $d^{\prime}{ }_{l}=$ $\min V\left(S_{i} \geq S_{k}\right)$

Menghitung normalitas vektor bobot dan nilai minimum dilakukan untuk memperoleh nilai masing-masing kriteria sehingga diperoleh prioritas dari kriteria tersebut.

$$
W=\left(d_{1}, d_{2}, \ldots, d_{n}\right)^{T}
$$

Dengan perumusan normalisasinya adalah:

$d_{l}=\frac{d^{\prime} l}{\sum_{i=1}^{n} d^{\prime} i} \operatorname{untuk} l=1,2, \ldots, \mathrm{n}(5)$

\section{Metode Penelitian}

Pengolahan data pada penelitian ini menggunakan bantuan program Excel, untuk mencapai tujuan penelitian digunakan metode FAHP. Adapun langkah-langkah analisis data dalam penelitian ini adalah:

1. Menyusun kriteria meliputi: suku bunga, promo/diskon, limit, dan iuran.

2. Menyebarkan kuisioner kepada responden dengan skala AHP yang telah ditetapkan menurut Saaty, T, L (1987).

3. Menyusun bobot nilai kriteria dari hasil rataan kuisioner yang telah diisi pada matriks berpasangan.

4. Menguji konsistensi hirarki. Jika tidak memenuhi dengan $\mathrm{CR}<0,100$ maka penilaian diulang dengan perbaikan perbandingan berpasangan.

5. Jika hasil memenuhi $\mathrm{CR}<0,100$ maka dilakukan pengubahan bobot penilaian perbandingan berpasangan pada skala AHP ke dalam bilangan triangular fuzzy.

6. Dari matriks triangular fuzzy ditentukan nilai fuzzy synthetic extent untuk tiap-tiap kriteria dan sub kriteria, dengan menggunakan persamaan (1).

7. Membandingkan nilai fuzzy synthetic extent $\left(S_{i} \geq S_{k}\right)$.

8. Dari hasil perbandingan nilai fuzzy synthetic extent maka diambil nilai minimumnya, yaitu: $d^{\prime}{ }_{i}=\min V\left(S_{i} \geq S_{k}\right)$

9. Menghitung normalitas vektor bobot dan nilai minimum dilakukan untuk memperoleh nilai masing-masing kriteria sehingga diperoleh prioritas dari kriteria tersebut dengan menggunakan persamaan (5). 


\section{Hasil dan Pembahasan}

Berdasarkan identifikasi data yang telah dilakukan dari hasil wawancara kemudian disusun menjadi sebuah struktur hirarki yang merupakan tujuan dari pemecahan masalah pengambilan keputusan dalam penelitian ini yaitu pemilihan kriteria dalam pembuatan kartu kredit. Kriteria yang telah dipilih adalah suku bunga, promo/diskon, limit, dan iuran tahunan. Selengkapnya dapat di lihat pada Gambar 1 berikut ini

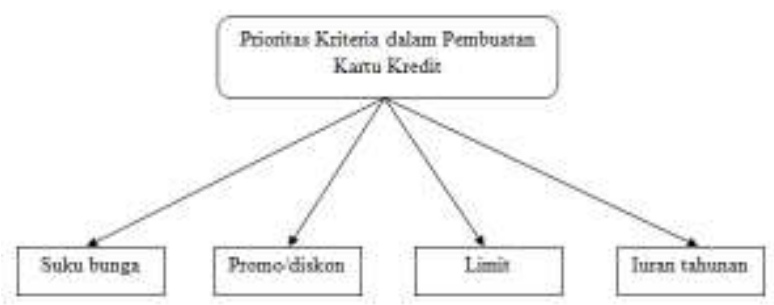

Gambar 1. Struktur Hirarki Kriteria

Pada langkah awal penelitian menyebar kuisioner kepada 50 responden yang mempunyai kartu kredit. Dari hasil kuisioner dibentuk matriks perbandingan antar kriteria. Dari sini setiap kriteria dicari nilai rataratanya. Selanjutnya nilai rata-rata dibulatkan ke nilai yang mendekati skala penilaian perbandingan berpasangan AHP yang terdapat pada Tabel 1. yaitu

a. 0.33676 mendekati $1 / 3$ yang merupakan kebalikan dari 3 yang artinya promo sedikit lebih penting dari pada suku bunga

b. 0.33656 mendekati $1 / 3$ yang merupakan kebalikan dari 3 yang artinya limit sedikit lebih penting dari pada suku bunga

c. 2.24428 mendekati 2 yang artinya suku bunga diantara sama penting dan sedikit lebih penting dari pada iuran tahunan

d. 0.3293 mendekati $1 / 3$ yang merupakan kebalikan dari 3 yang artinya limit sedikit lebih penting dari pada promo

e. 3.34028 mendekati 3 yang artinya promo sedikit lebih penting dari pada iuran tahunan f. $\quad 5.07324$ mendekati 5 yang artinya limit lebih penting dari pada iuran tahunan.

Dari perhitungan di atas diperoleh perbandingan berpasangan sebagai berikut:

Tabel 4. Matriks Perbandingan Berpasangan

\begin{tabular}{|l|l|l|l|l|}
\hline & \multicolumn{1}{|c|}{$\mathrm{A}$} & \multicolumn{1}{c|}{$\mathrm{B}$} & \multicolumn{1}{c|}{$\mathrm{C}$} & \multicolumn{1}{c|}{$\mathrm{D}$} \\
\hline $\mathrm{A}$ & 1 & $1 / 3$ & $1 / 3$ & 2 \\
\hline $\mathrm{B}$ & 3 & 1 & $1 / 3$ & 3 \\
\hline $\mathrm{C}$ & 3 & 3 & 1 & 5 \\
\hline $\mathrm{D}$ & $1 / 2$ & $1 / 3$ & $1 / 5$ & 1 \\
\hline
\end{tabular}

Selanjutnya untuk mendapatkan $\lambda_{\text {maksimum, }}$ langkah pertama adalah menghitung nilai vektor eigen yaitu: dengan cara mengalikan vektor perbandingan berpasangan untuk semua kriteria sampai mencapai nilai tertentu.

$\left[\begin{array}{cccc}1 & 0.333 & 0.333 & 2 \\ 3 & 1 & 0.333 & 3 \\ 3 & 3 & 1 & 5 \\ 0.5 & 0.333 & 0.2 & 1\end{array}\right] \times\left[\begin{array}{cccc}1 & 0.333 & 0.333 & 2 \\ 3 & 1 & 0.333 & 3 \\ 3 & 3 & 1 & 5 \\ 0.5 & 0.333 & 0.2 & 1\end{array}\right]$

$=\left[\begin{array}{cclr}4 & 2.331 & 1.177 & 6.664 \\ 8.499 & 4 & 2.265 & 13.665 \\ 17.5 & 8.664 & 4 & 25 \\ 2.599 & 1.433 & 0.667 & 4\end{array}\right]$

$\left[\begin{array}{cclr}4 & 2.331 & 1.177 & 6.664 \\ 8.499 & 4 & 2.265 & 13.665 \\ 17.5 & 8.664 & 4 & 25 \\ 2.599 & 1.433 & 0.667 & 4\end{array}\right] x\left[\begin{array}{cclr}4 & 2.331 & 1.177 & 6.664 \\ 8.499 & 4 & 2.265 & 13.665 \\ 17.5 & 8.664 & 4 & 25 \\ 2.599 & 1.433 & 0.667 & 4\end{array}\right]$

$=\left[\begin{array}{cccc}73.728 & 38.395 & 19.207 & 114.59 \\ 143.145 & 75.017 & 37.375 & 222.582 \\ 278.613 & 145.93 & 73.146 & 435.014 \\ 44.819 & 23.388 & 11.721 & 69.827\end{array}\right]$

$\left[\begin{array}{cccc}73.728 & 38.395 & 19.207 & 114.59 \\ 143.145 & 75.017 & 37.375 & 222.582 \\ 278.613 & 145.93 & 73.146 & 435.014 \\ 44.819 & 23.388 & 11.721 & 69.827\end{array}\right] x$

$\left[\begin{array}{cccc}73.728 & 38.395 & 19.207 & 114.59 \\ 143.145 & 75.017 & 37.375 & 222.582 \\ 278.613 & 145.93 & 73.146 & 435.014 \\ 44.819 & 23.388 & 11.721 & 69.827\end{array}\right]$
$\left.\begin{array}{cccc}21418.999 & 11193.973 & 5599.131 & 33351.317 \\ 41681.167 & 21783.484 & 10895.862 & 64901.301 \\ 81307.048 & 42492.880 & 21254.590 & 126602.912 \\ 13047.490 & 6818.883 & 3410.752 & 20316.166\end{array}\right]$

Setelah itu untuk mendapatkan nilai vektor eigen dari hasil perkalian terakhir vektor perbandingan berpasangan untuk semua kriteria yaitu dengan menjumlahkan setiap 
nilai baris dan hasil penjumlahan tersebut dijumlahkan kembali kemudian setiap elemen dibagi dengan jumlah tersebut sehingga diperoleh nilai vektor eigennya.

Tabel 5. Vektor Eigen

\begin{tabular}{|c|c|c|c|c|c|c|}
\hline & A & B & C & D & $\sum$ & $\begin{array}{c}\text { Vektor } \\
\text { Eigen }\end{array}$ \\
\hline A & 21418.99 & 11193.973 & 5599.131 & 33351.317 & 71563.421 & 0.136 \\
\hline B & 41681.16 & 21783.484 & 10895.862 & 64901.301 & 139261.81 & 0.265 \\
\hline C & 81307.04 & 42492.88 & 21254.59 & 126602.91 & 271657.43 & 0.516 \\
\hline D & 13047.49 & 6818.883 & 3410.752 & 20316.166 & 43593.290 & 0.083 \\
\hline$\Sigma$ & & & & & 526075.89 & \\
\hline$\Sigma$ & & & &
\end{tabular}

Untuk mencari $\lambda_{\text {maksimum }}$ diperoleh dari mengalikan hasil perkalian terakhir vektor perbandingan berpasangan untuk semua kriteria dengan vektor eigen dan membagikan kembali terhadap vektor eigen $A^{k} v=\lambda^{k} v$. Maka diperoleh nilai $\lambda_{\text {maksimum }}$ sebagai berikut:

$\left[\begin{array}{lrrr}21418.999 & 11193.973 & 5599.131 & 33351.317 \\ 41681.167 & 21783.484 & 10895.862 & 64901.301 \\ 81307.048 & 42492.880 & 21254.590 & 126602.912 \\ 13047.490 & 6818.883 & 3410.752 & 20316.166\end{array}\right] x$
$\left[\begin{array}{l}0.136 \\ 0.265 \\ 0.516 \\ 0.083\end{array}\right]=\left[\begin{array}{c}11531.888 \\ 22440.975 \\ 43775.524 \\ 7024.722\end{array}\right]$

$\left[\begin{array}{r}11531.888 / 0.136 \\ 22440.975 / 0.265 \\ 43775.524 / 0.516 \\ 7024.722 / 0.083\end{array}\right]=\left[\begin{array}{l}84773.045 \\ 84773.113 \\ 84773.131 \\ 84773.080\end{array}\right]$

Jadi, $\lambda_{\text {maksimum }}=\sqrt[6]{84773.131}$

$$
=4.131
$$

Karena matriks berordo 4 (yakni terdiri dari 4 kriteria), nilai indeks konsistensi yang diperoleh:

$$
\begin{aligned}
\mathbf{C I}=\frac{\lambda_{\max }-n}{n-1}=\frac{4.131-4}{4-1} \\
=\frac{0.131}{3} \\
=0.044
\end{aligned}
$$

Berdasarkan Tabel 2 Untuk $n=4$, maka $R I=$ 0.89, maka:

$$
\mathbf{C R}=\frac{\boldsymbol{C I}}{\boldsymbol{R I}}=\frac{0.044}{0.89}=0.049
$$

Karena $C R<0,100$ berarti preferensi responden adalah konsisten, maka perbandingan berpasangan AHP diubah ke dalam perbandingan berpasangan fuzzy AHP yaitu sebagai berikut.

a) Membuat matriks perbandingan berpasangan fuzzy yaitu dengan cara menggantikan nilai skala AHP dengan nilai skala bilangan segitiga fuzzy yang terdapat pada Tabel 6

Tabel 6. Matriks Perbandingan Berpasangan Fuzzy AHP

\begin{tabular}{|c|c|c|c|c|c|c|c|c|c|c|c|c|}
\hline & \multicolumn{3}{|c|}{ A } & \multicolumn{3}{c|}{ B } & \multicolumn{5}{c|}{ C } & \multicolumn{3}{c|}{ D } \\
\cline { 2 - 15 } & 1 & $\mathrm{~m}$ & $\mathrm{u}$ & 1 & $\mathrm{~m}$ & $\mathrm{u}$ & $\mathrm{l}$ & $\mathrm{m}$ & $\mathrm{u}$ & $\mathrm{l}$ & $\mathrm{m}$ & $\mathrm{u}$ \\
\hline $\mathrm{A}$ & 1 & 1 & 1 & $1 / 2$ & $2 / 3$ & 1 & $1 / 2$ & $2 / 3$ & 1 & $1 / 2$ & 1 & $3 / 2$ \\
\hline $\mathrm{B}$ & 1 & $3 / 2$ & 2 & 1 & 1 & 1 & $1 / 2$ & $2 / 3$ & 1 & 1 & $3 / 2$ & 2 \\
\hline $\mathrm{C}$ & 1 & $3 / 2$ & 2 & 1 & 1.5 & 2 & 1 & 1 & 1 & 2 & $5 / 2$ & 3 \\
\hline $\mathrm{D}$ & $2 / 3$ & 1 & 2 & $1 / 2$ & $2 / 3$ & 1 & $1 / 3$ & $2 / 5$ & $1 / 2$ & 1 & 1 & 1 \\
\hline
\end{tabular}

b) Menghitung nilai fuzzy synthetic extent.

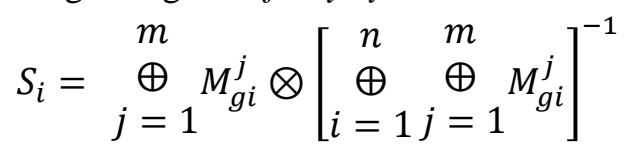

Untuk menghitung nilai fuzzy synthetic extent yang pertama adalah dengan menghitung nilai $\quad \underset{j=1}{\bigoplus} M_{g i}^{j}=$ $\left(\sum_{j=1}^{m} l_{j}, \sum_{j=1}^{m} m_{j}, \sum_{j=1}^{m} u_{j}\right)$ dengan operasi penjumlahan pada tiap-tiap bilangan triangular fuzzy dalam setiap baris.

Tabel 7. Nilai Fuzzy Synthetic Exten

\begin{tabular}{|c|c|c|}
\hline$l_{A, B, C, D}$ & $m_{A, B, C, D}$ & $u_{A, B, C, D}$ \\
\hline $5 / 2$ & $10 / 3$ & $9 / 2$ \\
\hline $7 / 2$ & $28 / 6$ & 6 \\
\hline 5 & $13 / 2$ & 8 \\
\hline $15 / 6$ & $46 / 15$ & $9 / 2$ \\
\hline
\end{tabular}


Kemudian menghitung

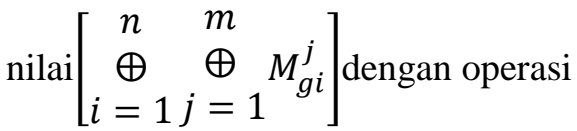
penjumlahan untuk keseluruhan bilangan triangular fuzzy dalam matriks perbandingan berpasangan.

Tabel 8. Jumlah Fuzzy Synthetic Extent

\begin{tabular}{|c|c|c|c|}
\hline & $l_{A, B, C, D}$ & $m_{A, B, C, D}$ & $u_{A, B, C, D}$ \\
\hline $\mathrm{A}$ & 2.5 & 3.333 & 4.5 \\
\hline $\mathrm{B}$ & 3.5 & 4.667 & 6 \\
\hline $\mathrm{C}$ & 5 & 6.5 & 8 \\
\hline $\mathrm{D}$ & 2.5 & 3.067 & 4.5 \\
\hline$\sum$ & 13.5 & 17.567 & 23 \\
\hline
\end{tabular}

Jadi untuk nilai $\left[\begin{array}{c}n \\ \underset{i=1}{\oplus} \bigoplus_{i} M_{g i}^{j}\end{array}\right]^{-1}$ adalah

$$
\left(\frac{1}{23}, \frac{1}{17.567}, \frac{1}{13.5}\right)
$$

selanjutnya dihitung nilai fuzzy syntethic extent untuk tiap kriteria utama dengan.

$S_{1}=(2.5,3.334,4.5) \otimes\left(\frac{1}{23}, \frac{1}{17.567}, \frac{1}{13.5}\right)$

$=(0.109,0.189,0.333)$

$S_{2}=(3.5,4.667,6) \otimes\left(\frac{1}{23}, \frac{1}{17.567}, \frac{1}{13.5}\right)$

$=(0.152,0.266,0.444)$

$\mathrm{S}_{3}=(5,6.5,8) \otimes\left(\frac{1}{23}, \frac{1}{17.567}, \frac{1}{13.5}\right)$

$=(0.217,0.369,0.593)$

$\mathrm{S}_{4}=(2.5,3.067,4.5) \otimes\left(\frac{1}{23}, \frac{1}{17.567}, \frac{1}{13.5}\right)$

$=(0.109,0.175,0.333)$

Jadi nilai fuzzy syntethic extent untuk tiap kriteria dapat dilihat pada Tabel 9

Tabel 9. Nilai fuzzy syntethic extent untuk tiap kriteria utama

\begin{tabular}{|c|c|c|c|}
\hline & $l$ & $m$ & $u$ \\
\hline S1 & 0.109 & 0.189 & 0.333 \\
\hline S2 & 0.152 & 0.266 & 0.444 \\
\hline S3 & 0.217 & 0.369 & 0.593 \\
\hline S4 & 0.109 & 0.175 & 0.333 \\
\hline
\end{tabular}

c) Menghitung perbandingan tingkat kemungkinan antar fuzzy syntethic extent dengan nilai minimumnya.

Langkah pertama adalah memperbandingkan nilai setiap fuzzy syntethic extent $\mathrm{V}\left(S_{2} \geq S_{1}\right)$,yaitu:

$$
\begin{aligned}
& =\left\{\begin{array}{cc}
1, & \text { jikam }_{2} \geq m_{1} \\
0, & \text { jikal }_{1} \geq u_{2} \\
l_{1}-u_{2} & \text { lainnya }
\end{array}\right. \\
& \mathrm{V}\left(\mathrm{S}_{1} \geq \mathrm{S}_{2}\right)=\frac{0.152-0.333}{(0.189-0.333)-(0.266-0.152)}=0.702 \\
& \mathrm{~V}\left(\mathrm{~S}_{1} \geq \mathrm{S}_{3}\right)=\frac{0.217-0.333}{(0.189-0.333)-(0.369-0.217)}=0.392 \\
& \mathrm{~V}\left(\mathrm{~S}_{1} \geq \mathrm{S}_{4}\right)=1 \\
& \mathrm{~V}\left(\mathrm{~S}_{2} \geq \mathrm{S}_{1}\right)=1 \\
& \mathrm{~V}\left(\mathrm{~S}_{2} \geq \mathrm{S}_{3}\right)=\frac{0.217-0.444}{(0.266-0.444)-(0.369-0.217)}=0.688 \\
& \mathrm{~V}\left(\mathrm{~S}_{2} \geq \mathrm{S}_{4}\right)=1 \\
& \mathrm{~V}\left(\mathrm{~S}_{3} \geq \mathrm{S}_{1}\right)=1 \\
& \mathrm{~V}\left(\mathrm{~S}_{3} \geq \mathrm{S}_{2}\right)=1 \\
& \mathrm{~V}\left(\mathrm{~S}_{3} \geq \mathrm{S}_{4}\right)=1 \\
& \mathrm{~V}\left(\mathrm{~S}_{4} \geq \mathrm{S}_{1}\right)=\frac{0.109-0.333}{(0.175-0.333)-(0.189-0.109)}=0.941 \\
& \mathrm{~V}\left(\mathrm{~S}_{4} \geq \mathrm{S}_{2}\right)=\frac{0.152-0.333}{(0.175-0.333)-(0.216-0.152)}=0.665 \\
& \mathrm{~V}\left(\mathrm{~S}_{4} \geq \mathrm{S}_{3}\right)=\frac{0.217-0.333}{(0.175-0.333)-(0.369-0.217)}=0.374
\end{aligned}
$$

Setelah didapat nilai perbandingan dari setiap fuzzy syntethic extent lalu diambil nilai minimumnya, yaitu:

$$
\begin{aligned}
& d_{i}^{\prime}=\min V\left(S_{i} \geq S_{k}\right) \text { untuk } k=1,2, \ldots, n ; k \neq i . \\
& d^{\prime}{ }_{1}=\mathrm{V}\left(\mathrm{S}_{1} \geq \mathrm{S}_{2}, \mathrm{~S}_{3}, \mathrm{~S}_{4}\right) \\
& =\min (0.702,0.392,1) \\
& =0.392 \\
& \begin{aligned}
d^{\prime}{ }_{2}=\mathrm{V}\left(\mathrm{S}_{2} \geq \mathrm{S}_{1}, \mathrm{~S}_{3}, \mathrm{~S}_{4}\right) \\
=\min (1,0.688,1) \\
=0.688
\end{aligned} \\
& \begin{aligned}
d^{\prime}{ }_{3}=\mathrm{V}\left(\mathrm{S}_{3} \geq \mathrm{S}_{1},\right. & \left.\mathrm{S}_{2}, \mathrm{~S}_{4}\right) \\
& =\min (1,1,1) \\
& =1
\end{aligned} \\
& \begin{aligned}
d^{\prime}{ }_{4}=\mathrm{V}\left(\mathrm{S}_{4} \geq \mathrm{S}_{1},\right. & \left.\mathrm{S}_{2}, \mathrm{~S}_{3}\right) \\
& =\min (0.941,0.665,0.374) \\
& =0.374
\end{aligned}
\end{aligned}
$$


Kemudian dilakukan perhitungan bobot dan normalisasi vektor bobot sehingga diketahui nilai bobot kriteria utama.

$W^{\prime}=\left(d^{\prime}{ }_{1}, d^{\prime}{ }_{2}, d^{\prime}{ }_{3}, d^{\prime}{ }_{4}\right)^{T}$

$\mathrm{W}^{\prime}=(0.392,0.688,1,0.374)$

danW $=\left(\mathrm{d}_{1}, \mathrm{~d}_{2}, \mathrm{~d}_{3}, \mathrm{~d}_{4}\right)^{\mathrm{T}}$ dengan $d_{l}=\frac{d^{\prime l}}{\sum_{i=1}^{n} d{ }^{\prime} i}$

menghasilkan normalisasi vektor bobot antar kriteria utamanya yaitu:

$\mathrm{W}=(0.16,0.28,0.408,0.152)$

Dari uji konsistensi dapat dilihat bahwa bobot prioritas pada kriteria utama yaitu limit $\left(d_{3}\right)$, promo/diskon $\left(d_{2}\right)$, suku bunga $\left(d_{1}\right)$, dan iuran $\left(d_{4}\right)$, adalah $0.408,0.28,0.16$, dan 0.152 .

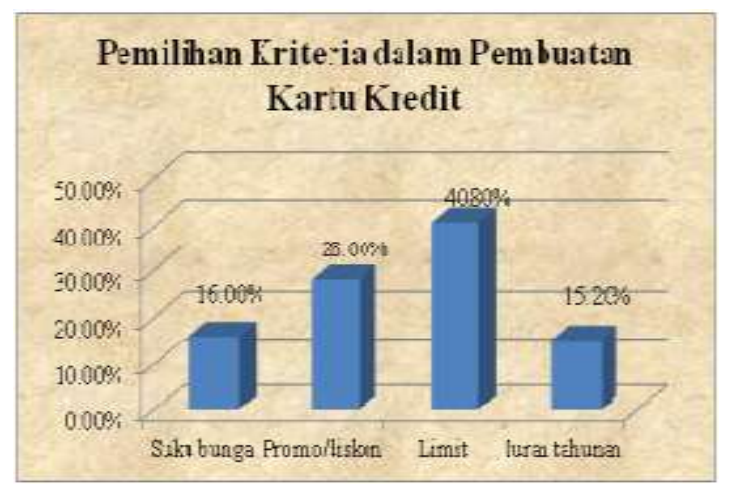

Gambar 2. Bobot Prioritas Pemilihan Kriteria dalam Pembuatan Kartu Kredit

\section{Kesimpulan}

Berdasarkan hasil yang telah diperoleh pada kasus Pemilihan Kriteria dalam Pembuatan Kartu Kredit, maka dapat ditarik kesimpulan bahwa metode Fuzzy AHP dapat digunakan untuk menentukan bobot prioritas pada masing-masing kriteria. Dari hasil analisis bobot prioritas pada kriteria utama dengan Fuzzy AHP, kriteria limit mempunyai pengaruh paling besar bagi nasabah dalam menggunakan kartu kredit sebesar 40.8\%, sedangkan promo/diskon sebesar $28 \%$, suku bunga sebesar $16 \%$ dan yang terakhir adalah iuran tahunan sebesar $15,2 \%$. Dari melihat hasil total rangking di atas, disarankan kepada bank-bank agar dapat melihat peluang yang lebih baik untuk memberikan penawaran- penawaran dalam menarik nasabah untuk membuat kartu kredit

\section{Daftar Pustaka}

Apriyanto, Agus, 2008, Perbandingan Kelayakan Jalan Beton dan Aspal dengan Metode Analityc Hierarchy Process (AHP) (Studi Kasus Jalan Raya DemakGodong), Thesis tidak diterbitkan, Semarang, Program Pascasarjana Universitas Diponegoro

Budhi, Wono Setya, 1995. Aljabar Linier. Jakarta:Gramedia Pustaka Utam

Chang, D.Y., 1992, Extent Analysis and Synthetic Decision, Optimization Techniques and Applications, World Scientific, Singapore, 1:352 1996. Applications of The Extent Analysis Method on Fuzzy AHP. European Jurnal of Operational Research, 95, 649-655.

Kusumadewi, Sri dan Hari Purnomo, 2010, Aplikasi Logika Fuzzy Untuk Pendukung Keputusan, Edisi 2, Graha Ilmu, Yogyakarta

Saaty, T, L, 1987, Uncertainty and Rank Order in The Analytic Hierarchy Process. European Journal of Operation Research $32: 27-37$

Saaty, T, L, and L, G. Vargas, 2012. Models, Methods, Concepts \& Applications of the Analytic Hierarchy Process, International Series in Operations Research \& Management Science, Vol. 175, $2^{\text {nd }}$ edition. New York: Springer

Suyatno, T., dkk. 1997. Dasar-dasar Perkreditan. Jakarta : PT. Gramedia Pustaka Utama. 